\title{
Women's Civil and Political Rights in Lebanon and France and Their Impact on Economic Growth
}

\author{
Mahmoud MOURAD \\ Professor of Econometrics and Quantitative methods at Lebanese University \\ Faculty of Economic Sciences and Business Administration-Branch (5) \\ E-mail: mourad.ul@gmail.com; mmrad@ul.edu.lb \\ Rim FARHAT \\ Assistant Professor of Law at Lebanese University \\ Faculty of Economic Sciences and Business Administration-Branch (5) \\ E-mail: dr.farhat_rim@hotmail.com
}

Received: Jan. 18, 2020 Accepted: Feb. 10, 2020 Online published: Feb. 17, 2020

doi:10.5296/jpag.v10i1.16489 URL: https://doi.org/10.5296/jpag.v10i1.16489

\begin{abstract}
This study carried out a quantitative analysis of several variables in both Lebanon and France. Specific aspects related to education, unemployment, vulnerable employment, gender gap, and participation in parliamentary life were studied. We started from the rationale that human rights necessitate that human beings so it is imperative that each individual enjoy civil and political rights, which means in addition to the right to life and the right equality, there should be the right to the legal recognition and participation in public life whether through employment or elections. These rights have been recognized by the international human rights laws, mainly in the Universal Declaration of Human Rights by United Nations and by the existing local laws both in Lebanon and France.

The tests of homogeneity for the panel data models from Lebanon and France have been implemented carefully considering the linear relationship between the real GDP as a dependent variable (Y) and three of the independent variables consisting of the rate of women teachers in the secondary education $\left(\mathrm{X}_{3}\right)$, the rate of female to male ratio in labor force participation $\left(\mathrm{X}_{5}\right)$, the rate of women's vulnerability to risks in the female labor force $\left(\mathrm{X}_{6}\right)$. The study demonstrated the importance of the Random Effects Model (REM) using the the log-transformed data. The study revealed a positive impact of both $\mathrm{X}_{3}$ and $\mathrm{X}_{5}$ on the real
\end{abstract}


GDP (Y) while the variable $\left(\mathrm{X}_{6}\right)$ has a negative impact both in Lebanon and France during the period (2008-2017).

Keywords: civil and political rights, female labor force, vulnerable employment of female, women teachers in higher education, economic growth, panel data model

\section{Introduction}

Women have long suffered from the injustice of their rights in various human societies, so that the cry of religion and thinkers was not to treat women as second-class human beings, but rather to say equality in the perception of humanity on the one hand and in civil rights on the other. Since human societies are divided into two equal groups, i.e. about $50 \%$ of women and $50 \%$ of men, neglecting the role of women at all levels of economic and cognitive productivity will have a negative impact on economic growth, economic development and even civil peace in every country. We do not want our study to delve much into the historical aspect of the reality of women in the world, but only to focus on several economic and social variables that attempt to uncover each other to illustrate the gap between the reality of women in Lebanon and their reality in France as the Lebanese Constitution and the provisions contained therein women in all respects is the same constitution inspired by the French experience itself.

The most important means of eliminating gender differences is by allowing women to participate. Participation is the recognition of the equal rights of groups and individuals to manage their own affairs, to control their own destinies, to accept the other and to be considered as full-fledged and humane regardless of sex, religion, race or colour ${ }^{1}$. The political participation is a human right that is fundamentally based on equality, which means the right of the human person to acquire his or her rights and to fulfil his or her obligations on an equal footing with his or her peers who enjoy the same rights and duties. It is therefore not permissible to discriminate on grounds of race, colour, language, religion, political or other opinion, national or social origin, property, birth or other status, without distinction between men and women.

Women's right to participation and non-discrimination has been the subject of international and domestic conventions, as we find:

a- Charter of the United Nations article 1: "to achieve international cooperation... To promote and encourage respect for human rights and fundamental freedoms for all without distinction as to sex, language or religion, and no distinction between men and women".

b- The Universal Declaration of Human Rights recognized the human right to equality and non-discrimination ${ }^{(2)}$, (Article 1).

${ }^{1}$ Political participation, online article: http://www.rdflwomen.org

2 Adopted by the General Assembly of the United Nations unanimously by the participating States on 10 December, 1948. 
c- International Covenant on Civil and Political Rights ${ }^{(3)}$ (ICCPR), which emphasized the equality of men and women in the enjoyment of all civil and political rights. (Article III)

a- Convention on the Elimination of All Forms of Discrimination against Women ${ }^{(4)}$ "CEDAW-" CEDAW.

To determine the role of women in participation in both countries, Lebanon and France, we have chosen the role of women in three rights: the right to education, the right to work, and the right to political participation. No doubt, the situation of women in society has an impact on the economic growth especially the share of women in the labor force and their role in the national decision-making. After establishing the position of the women according to Lebanese and French Constitutions, our study will address the following variables:

a- Female unemployment (\% of female labor force): $\left(\mathrm{X}_{1}\right)$

b- Percentage of females in higher education: $\left(\mathrm{X}_{2}\right)$

c- Percentage of females in secondary education: $\left(\mathrm{X}_{3}\right)$

d- Percentage of females in primary education: $\left(\mathrm{X}_{4}\right)$

e- Female-to-male ratio in the labor force: $\left(\mathrm{X}_{5}\right)$

f- Female vulnerable employment (\% of female employment): $\left(\mathrm{X}_{6}\right)$

g- Female labor force participation (\% of female population ages 15-64): $\left(\mathrm{X}_{7}\right)$

h- Gender gap: $\left(\mathrm{X}_{8}\right)$

i- Ratio of seats in parliament: $\left(\mathrm{X}_{9}\right)$

j- $\quad$ Female labor force $\left(\%\right.$ of total labor force) $\left(\mathrm{X}_{10}\right)$

Due to the lack of data (ten years for each country), we will firstly sort the variables considering the presence of multicollinearity among them, which allows us to categorize them within groups according to the importance of the bivariate Pearson's correlation coefficient. If a correlation coefficient is very high, i.e. close to $(\mp 1)$ then one of the group can be adopted in the panel data model. We will not use a complex technical model of econometric, but we will pay attention to the statistical descriptive aspect, specially on the Pearson's correlation coefficients for all couples of the independent variables, without forgetting the fundamental statistical characteristics for each variable. Secondly, we will focus on the panel data model that will be appropriate to monitor the relationship between the selected explanatory variables and the real GDP ${ }^{5}$.

\footnotetext{
3 Adopted by the General Assembly of the United Nations on 16 December 1966

${ }^{4}$ Adopted by the General Assembly of the United Nations on 18 December 1979.

${ }^{5}$ For the France, the Consumer Price Index (base year 2008) was used for a website: https://fred.stlouisfed.org/help-faq, while concerning data on Lebanon, they are collected at
} 


\section{MlMacrothink}

Journal of Public Administration and Governance

ISSN 2161-7104

2020, Vol. 10, No. 1

The paper consists of seven sections. The introduction is in the first section. In the second section, the aspects of human rights related to women in Lebanon and France will be presented. The third section will be devoted to a descriptive study of variables while the fourth section will be designed to the choice of the explanatory variables for the panel data model, the fifth section will be intended to a brief literature review, while the sixth section will be focused on the three panel data models used frequently in econometrics, more precisely, the pooled regression model, the fixed effects model and the random effects model, and finally the seventh section will be reserved to the conclusion and recommendations.

\section{Human Rights Related to Women}

In this section, the rights associated with education, work, and political participation will be presented.

\subsection{Right to Education ${ }^{(6)}$}

Education is the opportunity for everyone to have access to the knowledge and information they need since childhood, and is a human right, given its importance to the individual itself and its positive reflection on the development of society and the development of States.

The State has the primary responsibility for securing the right to education for all individuals in its territory, by imposing compulsory education, providing for it in its domestic law, refraining from any action that may prevent or limit access to education, and to provide the necessary resources to finance education, the establishment of formal schools and universities and the supervision of special education. Education must be at least at the primary and basic levels free of charge, with universal secondary education of all kinds, including technical and vocational secondary education, and higher education accessible to all Equal footing, depending on efficiency.

The right to education has been enshrined in a number of international human rights conventions, to which Lebanon and France are parties, including:

a- article 26 of the Universal Declaration of Human Rights.

b- UNESCO Convention against Discrimination in Education 1960.

c- Articles 13 and 14 of the International Covenant on Economic, Social and Cultural Rights, 1966.

d- Convention on the Rights of the Child, articles 28 to 30.

e- Convention on the Elimination of All Forms of Discrimination against Women-CEDAW, Article 10, sets out the measures that States parties to the Convention are required to take to

the Central Administration of Statistics(CAS): http://www.cas.gov.lb

${ }^{6}$ Report of the Special Rapporteur on the right to education, Kishore Singh: Justiciability of the right to education, Human Rights Council, twenty-third session, agenda item 3-Promotion and protection of all human rights, civil, political, economic, social and cultural, including the right to development, United Nations General Assembly, 10-5-2013. 
eliminate discrimination against women in order to ensure that they have equal rights with men in the field of education by securing:

e1- Equal conditions in career and vocational guidance, enrolment in studies and access to degrees in educational institutions of different categories.

e2- Equality in school curricula, in examinations, in access to scholarships and other study grants, and in opportunities for access to programmes of continuing education, including adult education and literacy programmes Career, and opportunities to participate in sports and physical education.

e3- Reduction of student drop-out rates.

In France:

There are many laws that have sponsored the right to education and have been compulsory and have given women this right in France for a very long time, including the education system in France:

a- To open secondary education for girls in the year 1880 .

b- To adopt the compulsory education system between the ages of 6 and 13 and free for both girls and boys, in 1882.

c- The Falox Act (1850), which obliges municipalities with more than 800 inhabitants to open a special primary school for girls.

d- In 1924 the curriculum for males and females was standardized and a bachelor's degree was established.

e- Open Technical Education for girls in 1965.

f- In 1959, President de Gaulle issued special decrees raising the age of compulsory to 16 years.

g- The decision of the French President to reduce the age of compulsory education from six to three years from the academic season of $2019^{(7)}$.

In Lebanon:

The Lebanese Constitution recognized freedom of education, without providing for the right to education, while the national consensus document emphasized that education and freedom should be provided, protection of special education, reform of formal education and curriculum review, and compulsory education at least at the primary level ${ }^{(8)}$.

Free education had been approved, and several decisions had been issued exempting pupils

7 Lowering the age of compulsory education in France, March 27, 2018. http://www.alhayat.com/article/

${ }^{8}$ Right to education, national human Rights Plan, background Study Series, House of Representatives, parliamentary Human Rights Committee in collaboration with UNDP, 2008. 
from school fees in public schools, and many state-owned and professional schools and the Lebanese University had been established.

However, we do not find any provision in Lebanese law that discriminates on the basis of sex with education, which means that the right of women to equality with men is obtained without any discrimination in legal terms.

\subsection{Right to Work}

The right to work is to give everyone the opportunity to earn a living by performing work freely chosen or acceptable, which is a right of every individual and a basis for the realization of human rights and the enjoyment of a dignified life ${ }^{(9)}$.

This right is secured by the State by taking the necessary measures to promote productive employment opportunities and ensuring that discrimination is not practised in all aspects of work, ensuring just and favourable conditions of work, in particular the requirement of equal pay for work of equal value.

The right to work in international conventions:

a- Articles: 23 and 24 of the Universal Declaration of Human Rights.

b- Articles 6 and 7 of the International Covenant on Economic, Social and cultural rights.

c- International Labor Convention.

d- Convention No. 100 on equal remuneration for men and workers for work of equal value $^{(10)}$.

e- Convention on the Elimination of All Forms of Discrimination against Women-CEDAW, Article 11.

Article 11 of the CEDAW Convention sets out the measures to be taken by State parties to eliminate discrimination against women in the field of employment, including:

e1- The right to work as an inalienable right of all human beings and to enjoy the same employment opportunities.

e2- The right to free choice of profession and type of employment, the right to promotion, job security and all benefits and conditions of service, and the right to receive vocational training and retraining.

e3- The right to equal remuneration and to be treated in respect of work of equal value.

e4- The right to paid leave.

e5-The right to protection of health and to safety in working conditions, including the

9 The right to work, through the Internet, the global network of economic, social and cultural Rights, https://www.escr-net.org/ar/resources.

10 Adopted by the General Conference of the International Labor Organization on 29 June 1951. 
safeguarding of the function of reproduction.

e6- Prohibition of dismissal on the grounds of pregnancy or maternity leave, introduction of paid maternity leaves and special protection for women during pregnancy in work proved to be harmful to them.

In France:

a- A married woman who works has the right to dispose of her salary (in 1907).

b- The law of 8 weeks' maternity leave, without Pay (1909), then paid in 1928.

c- In 1946 the concept of "women's wages" was abolished.

d- To leave a married woman in 1965 to practise a profession without the permission of her husband.

e- 1971 Law on equal pay for men and women for equal work.

f- Act 1983, which prohibits any occupational discrimination on the grounds of sex.

In Lebanon:

a- Article 12 of the Constitution recognizes the right of every Lebanese person to take up public office, which has no advantage over the other, except in terms of merit. Eligibility and merits according to the conditions prescribed by law.

b- A Special Ministry of Labor has also been established, and the legislator has adopted many legal texts that govern the right to work, given the importance of this right, including: The Labor Code, the Staff Regulations, the Collective Labor Contracts Act, mediation and arbitration.

The Lebanese law has granted women some rights commensurate with their nature, such as:

a- To grant women 10 weeks of paid maternity leave, articles 28 and 29 of the Labor Code and article 38 of the Staff Regulations.

b- To prevent the dismissal or the warning of women during the period of maternity leave, article 28 and 29 of the Labor Code ${ }^{(11)}$.

c- abolish discrimination by compensation and assistance by amending articles 3, 5, 6 and 7 of Decree No. 3950 of 27-5-1960 (Compensation and assistance system) by decision No. 29 of the Council of Ministers dated 3-4-2012.

d- The Labor Code prohibits the employer from discrimination or segregation (art. 26)

e- The law on employees in the public sector has equated the employee and employee in the system of retirement and dismissal from service and benefit from education grants.

11 The period was increased to 10 weeks by Law No. 267/2014: Amending the provisions of articles 28 and 29 of the Labor Code, and Law 266/2014 amending the provisions of article 38 of the Staff Regulation Legislative Decree No. 112/1959. 
f- recognition of commercial Capacity (1994).

Through the foregoing, French law and Lebanese law are constantly evolving and amending its provisions in order to try to eliminate discrimination between men and women at work, but the legal reality shows a disparity in wages and dealings between women and men, and a gap between the sexes. Has not been able to Day of their removal.

\subsection{Political Participation}

One of the prerequisites for ensuring human rights is that the individual is respected and effective in the existing political system, by granting him or her the right to participate in the formation of the existing political system as a candidate and an election. The political participation $^{(12)}$ consists in the participation in the political and popular expression and the conduct of public affairs by the Parties of society, both women and men, is the finest expression of democracy because it is based on the contribution of citizens in public issues, and the sites of influence in the fact that it enables people to get or defend their rights and interests, which ultimately gives them the ability to control their own lives and contribute to the direction of the life of society in general. Every member of society has the right to participate in the development process and to have equal opportunities in decision-making through the legislature, the local authorities or the parties.

The political participation is a human right, which has been recognized in a number of International Conventions ${ }^{13}$ :

a- The Universal Declaration of Human Rights, since everyone has the right to take part in the conduct of the public affairs of his country either directly or through freely chosen representatives (art. 21).

b- International Covenant on Civil and Political Rights (art. 25).

c- Convention on the Political Rights of women ${ }^{(14)}$.

d- Convention on the Elimination of All Forms of Discrimination against Women-CEDAW, Article 7.

Article 7 of the CEDAW Convention sets out the measures that States parties must take to eliminate discrimination against women in the political and public life of the country and, in particular, to ensure to women, on equal terms with men, the right:

d1- Voting in all elections and public referendums, and eligibility for election to all bodies elected its members by universal suffrage.

d2- Participation in the formulation of government policy and in the implementation of this policy.

The women's political participation has paid great attention to the advancement and improvement of the status of women and their position in society, given the role women can

12 Political participation, previous article.

13 United Nations Human Rights Commission website, https://www.ohchr.org/en/

14 Adopted by the General Assembly of the United Nations on 20 December 1952. 
play in their participation in the public interest in the development of their rights, on the one hand, and the positive impact on society on the other. In order to improve women's participation in elections, there has been a talk and adoption of women's associations in many political systems, which is a system that preserves women's quotas to represent women on the basis of determining the proportion of the minimum number of seats or centres to be allocated to women ${ }^{(15)}$, which may not be less than Percentage prescribed by law.

Sometimes they may constitute an intervention that reduces the discriminatory gap between men's political participation and women's participation.

In France:

a- "Universal suffrage" for men in 1848.

b- The Women's Rights Association, which supports women's right to vote in 1876, was established.

a- To give women the right to vote and to be elected to parliament, following World War II, in 1945, in appreciation of their contributions to the armed struggle to liberate France from the Nazi occupation.

b- The law of 2000 aims to entrench the principle of equality between men and women in parliamentary representation, which imposes on every political current that half of its candidates are women.

c- The 2014 law increases the financial fines for parties that do not abide by the principle of equality in their electoral lists.

$\mathrm{n}$ French law, we note that women have the right to political participation and support for this right, but there is a time lag of about a century between granting men this right in France and giving it to women despite persistent demands.

\section{In Lebanon:}

a- The Lebanese Constitution, in its introduction, considers that the people are the source of the authorities and the sovereign exercised them through constitutional institutions (para. d). Every Lebanese citizen who has attained the age of 21 years has the right to be a voter, subject to the conditions required under the electoral law (article 21 of the Constitution).

b- In Lebanon, members of the parliament are elected directly by the people, as well as members of the municipal councils in accordance with the electoral law, and every person who has completed the age of 25 is entitled to stand for election, provided he has the right to vote.

15 "A Latin expression means an electoral system aimed at guaranteeing the rights of minorities in general elections to political power." Studies and researches confirm that more than eighty countries adopt this system throughout the world: women's quota is a right of the woman, http://hayatouki.com/my-rights-and-challenges/ 
c- The Electoral Law of 1953 recognized women's political rights, that is to say, to participate in elections and candidacy.

d- 2016 article 25 of the Municipalities Act has been amended to the right of a married woman to run in her hometown or in the husband's village on the basis of her choice.

In Lebanese law, we note that there is no discrimination between women's and men's right to stand for election, as women are entitled to run without a legal limit or special condition, and are eligible for election. However, the practical and effective exercise of this right is that women exercise their right to vote only in a large and effective manner, and their right to stand for election is very timid, given the small number of women candidates, the number of those who are actually elected, and there have been numerous claims by associations concerned with gender for the adoption of women's quotas in Election law but this did not happen and the last election Law (Act No. 44/2017) was promulgated without a specific quota for women's participation.

Comparing the history of women's granting of civil and political Rights, in particular women's right to political participation in 1945, and the actual number of participations today in France, between the date of granting the women's right in 1953 and the actual current number, we find a little time difference in return, a significant difference in participation rate.

\section{A Descriptive Study of the Variables}

First, for more information about the single and multiple linear regressions and estimation methods in the case of autocorrelation of errors and / or heteroskedastic errors, consult the book (Mourad M. , 2017). In Table (1) on the appendix, for each of the variables above, we calculated the main statistical characteristics as the means, the standard deviations, the minimum and the maximum. This table allows for a more precise description of the variables and their comparison between France and Lebanon. In France, the standard deviations related to higher education, secondary education and labor force, have values less than those of their corresponding values in Lebanon. This shows that the changes are relatively large in Lebanon. On the remaining variables, it seems the presence of variability is lower in Lebanon, which indicates that those variables don't change much with time and that's revealed by the convergence of the upper and lower values, and thus the variables are nearer to a constant in the mobility over time.

\subsection{Unemployment}

The unemployment is considered one of the economic variables that decision-makers dedicate enough policies to reduce, establish fixed rules for the economic growth and social peace attached with it. In this context, when we draw attention to the economic growth in a country, we need to look directly to the GDP growth and unemployment rates. This is recommended by the eminent economist (Okun, 1962). Since that date, economists speak "Okun's Law", which affects the statistical relationship between unemployment rate and economic growth in a particular country, showing how much of the country's gross domestic product (GDP) can be "wasted" when the rate of unemployment exceeds the natural rate. Okun's Law goes on to explain that the GDP depends on the amount of labor force employed 
in the manufacturing process, and comes to the conclusion that there is a negative relationship between unemployment growth and GDP growth (Mourad, 2017, 344-349). In the following charts, we will present unemployment rate in general, as well as male and female unemployment in both France and Lebanon.

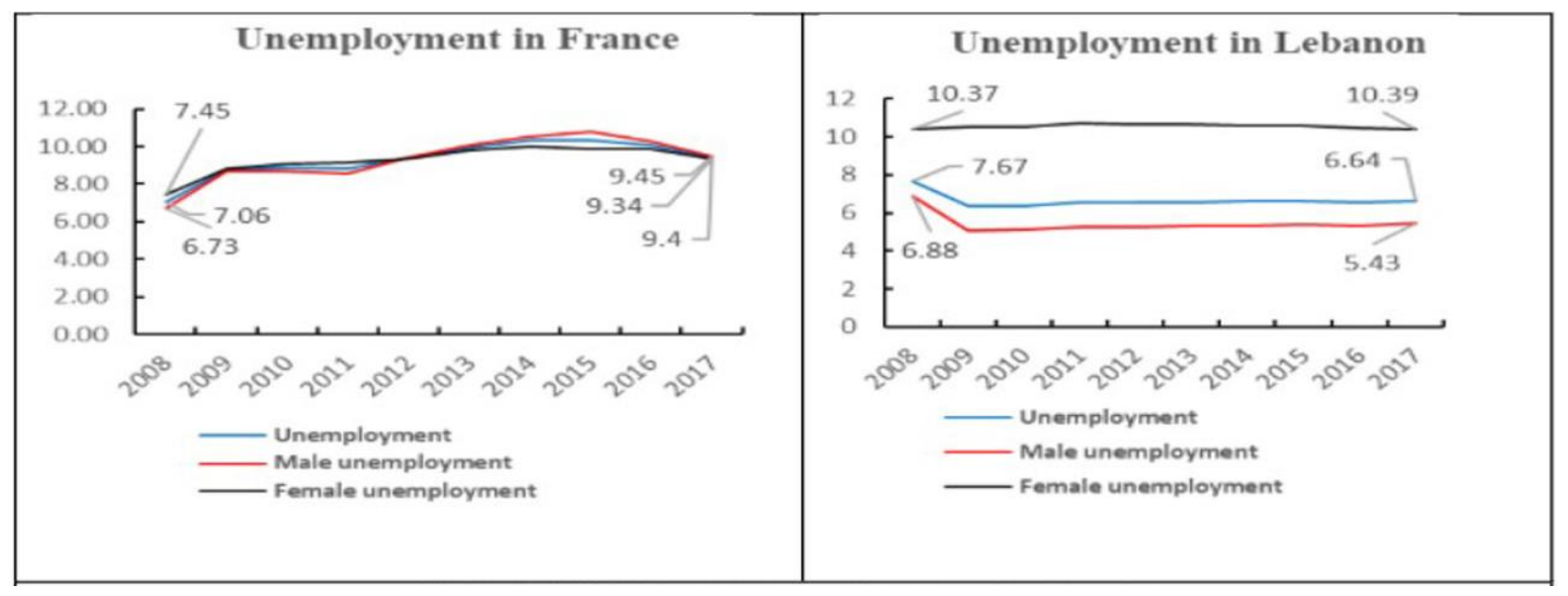

Figure 1. Unemployment in France and Lebanon

Before talking about the unemployment rates in the two countries, we would like to draw attention to the difference in the accuracy of the data in figure (1). In France, there is high accuracy in the data because the legislation obliges people in charge to do the registration and documentation of the mobility of the labor force and unemployment for both sexes. In Lebanon, there is no precise labor force and unemployment census and, consequently, the World Bank data on Lebanon do not reflect the reality of the detailed unemployment data. Furthermore, the Lebanese women's labor force contains an important part of the female foreign workers who work inside houses, as the Human Rights Watch organization estimated that there are 200 thousand workers in 2015. Based on World Bank data, the rate of female-labor force was about $24.45 \%$ of the total Lebanese labor force in 2017, approximately 539 thousand workers, which means that there are about 300 thousand Lebanese workers. Figure (1) indicates that the average rates of unemployment-females are $9.27 \%$ and $10.54 \%$ in France and Lebanon respectively

\subsection{Education}

There is no doubt that education plays a strategic role in the awakening, awareness and progress of peoples. It is a privilege of Lebanon to have people in all social strata. The educational movement monitor reveals that the flow of students to specialize at home and abroad characterizes all levels of education. Moreover, the labor market at different levels of education gives women a leading role where the high rates of women as teachers in all levels of education appears clearly (see figure (2)). In primary education, the female teachers cover about $88 \%$ of the total teachers, and this is the same result in France. But it is striking that, in 2017, the proportion of the Lebanese female teachers in the higher and secondary education exceeds their counterparts in France, which amounted to $70.64 \%$ compared to $59.89 \%$ in the secondary education and $52.19 \%$ compared with $40.92 \%$ in higher education. These results 
reflect the crystallization of a new culture in Lebanon showing that the Lebanese families have a strong focus on education of females as males, despite the harsh living conditions and this is a positive sign awarded for the Lebanese people. Unfortunately, this has not been reflected in the other productive sectors because, as mentioned earlier, women's participation in the labor force has remained weak.

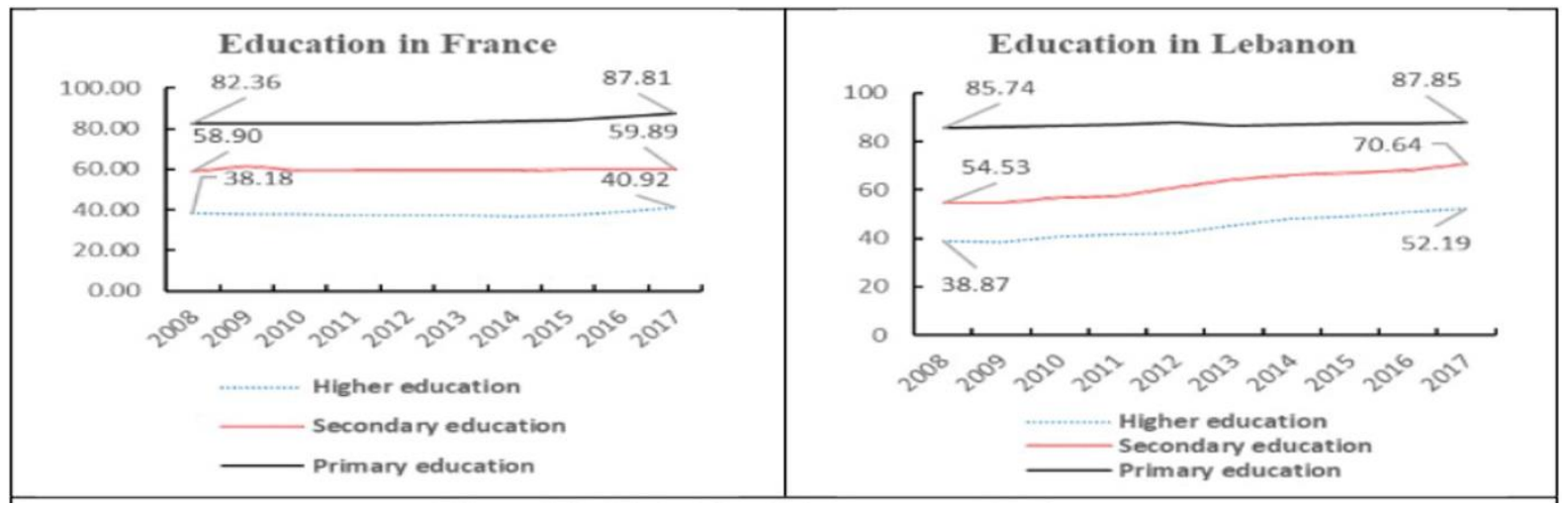

Figure 2. Education in France and Lebanon

\subsection{Female Labor Force}

Despite our reservation on the World Bank data relating to the Lebanese labor force, we have seen it useful to give an idea of the average of the available rates, especially the female-to-male ratio in the labor force that amounted in Lebanon to $32.59 \%$ in 2017 compared to $84.11 \%$ in France and this is a big difference because it reflects the zero tolerance in labor rights between the sexes, though the same rights exist in the Lebanese constitution. While it's different in France as shown in figure (3), where there is affinity between the female labor force $(46.97 \%)$ and the male labor force $(53.03 \%)$, it also appears that the general trend is linear and it increases very slowly from year to year.

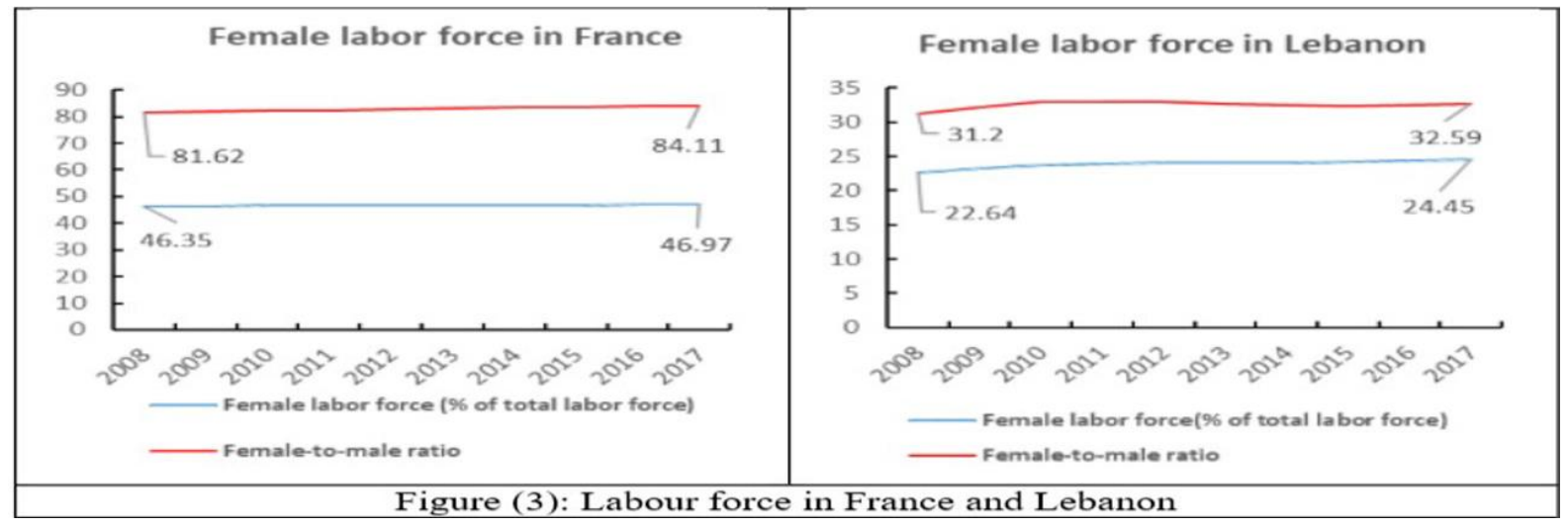

Figure 3. Labor force in France and Lebanon

\subsection{Female Vulnerable Employment}

We'll start with the definition of the vulnerable employment: according to the World Bank, there are individuals working without pay or who are self-employed persons. Their rate is 
calculated as a percentage of the total employment. For women's employment, the female vulnerable employment rate is the proportion of the total number of women employed. If the ratio is high, then this means that women are not up in protecting their rights to equality with men, which makes the community unconscious of women's skills. However, if it is destined to be, then it would contribute to development at all levels. Through figure (4), we note a significant difference in the proportion of the female employment of the total female age groups (15-64). In Lebanon, the rates range from $24.15 \%$ at a minimum and $25.9 \%$ at a maximum, while in France, the rates range from $65.13 \%$ at a minimum and $67.61 \%$ at a maximum. More accurately, in Lebanon, there is about a quarter of female age groups (15-64) participating in the labor force, while in France, the participation rate is about two-thirds of the female age groups. Regarding the female vulnerable employment in Lebanon, it ranged from $14.86 \%$ at a minimum and $15.91 \%$ at a maximum; probably, the rates are higher than that, while the percentage in France ranges between $4.8 \%$ and $6.05 \%$. Decision-makers in Lebanon must take the data published by World Bank into account and perform the necessary legal and social protection for this group of female vulnerable employment. Decision makers should work hard to ensure decent and stable employment for about (15\%) of the female vulnerable employment. Otherwise, leaving this high percentage rate of female vulnerable employment as is would be a form of corruption and a waste of human resources. Corruption is a deadly wedge for the advancement of the Arab countries (Mourad M. , 2018a)

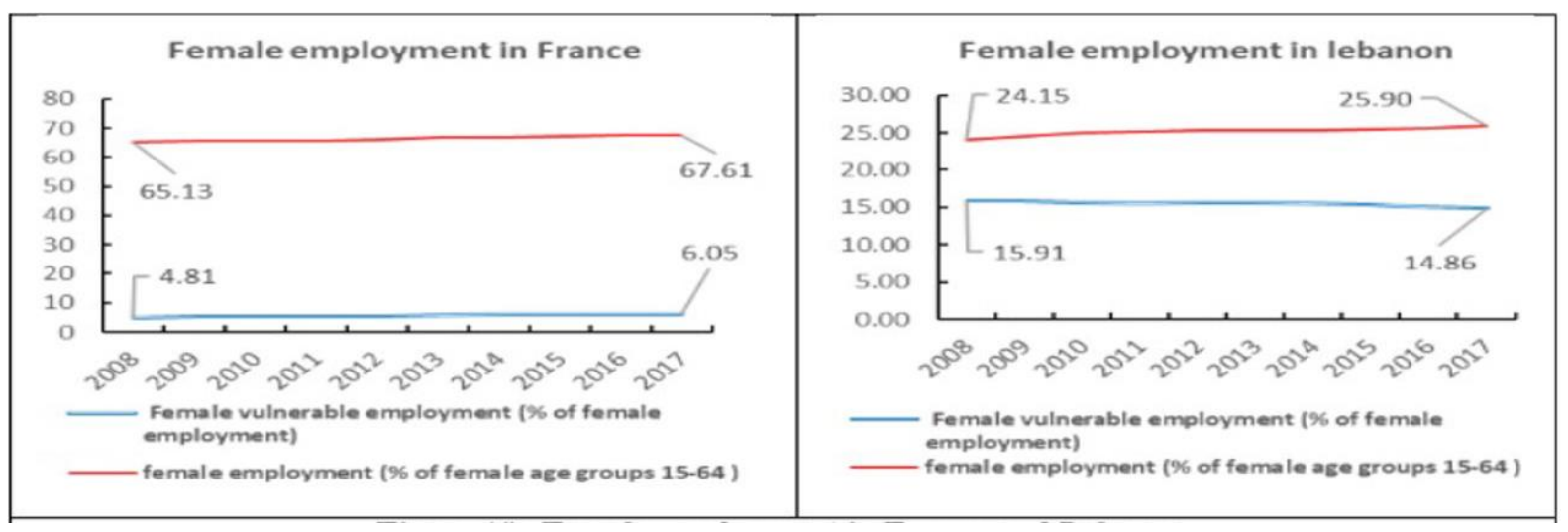

Figure 4. Female employment in France and Lebanon

\subsection{Gender Gap and Parliamentary Representation}

According to the World Economic Forum, gender gap or gender inequality is an indicator that sheds light on gender inequalities (Gender Gap Index GGI) that discriminate between the two genders-in social interactions and norms. The indicator is focused on four broad areas:

a- Economic participation and opportunity

b- Educational attainment

c- Health and survival

d- Political empowerment

Previewing the global data for Gender Gap Index GGI in 2017, we find the highest value in 


\section{Macrothink}

Journal of Public Administration and Governance

ISSN 2161-7104

2020, Vol. 10, No. 1

Iceland $(87.4 \%)$, Finland $(84.5 \%)$ and Norway $(84.2 \%)$, while the lowest values are observed in Yemen (51.6\%), Syria (56.8 \%) and Chad (57.5\%). Figure (5) indicates that the GGI in Lebanon is very close to the minimum and it varies from $(60.3 \%)$ in 2008 to $(59.6 \%)$ in 2017 while in France, the GGI varies from (73.4\%) in 2008 to (77.8\%) in 2017. Although women's participation in all levels of education is very high in Lebanon, both the economic participation and political empowerment remain very weak, pushing GGI to low limits. For the parliamentary representation, Lebanon is still included among the states which do not give women fair opportunities to participate in the parliament. In 2017, the female participation rate recorded $(3.1 \%)$ in Lebanon, $(3.1 \%)$ in Kuwait, $(0 \%)$ in New Guinea and $(0 \%)$ in Qatar.

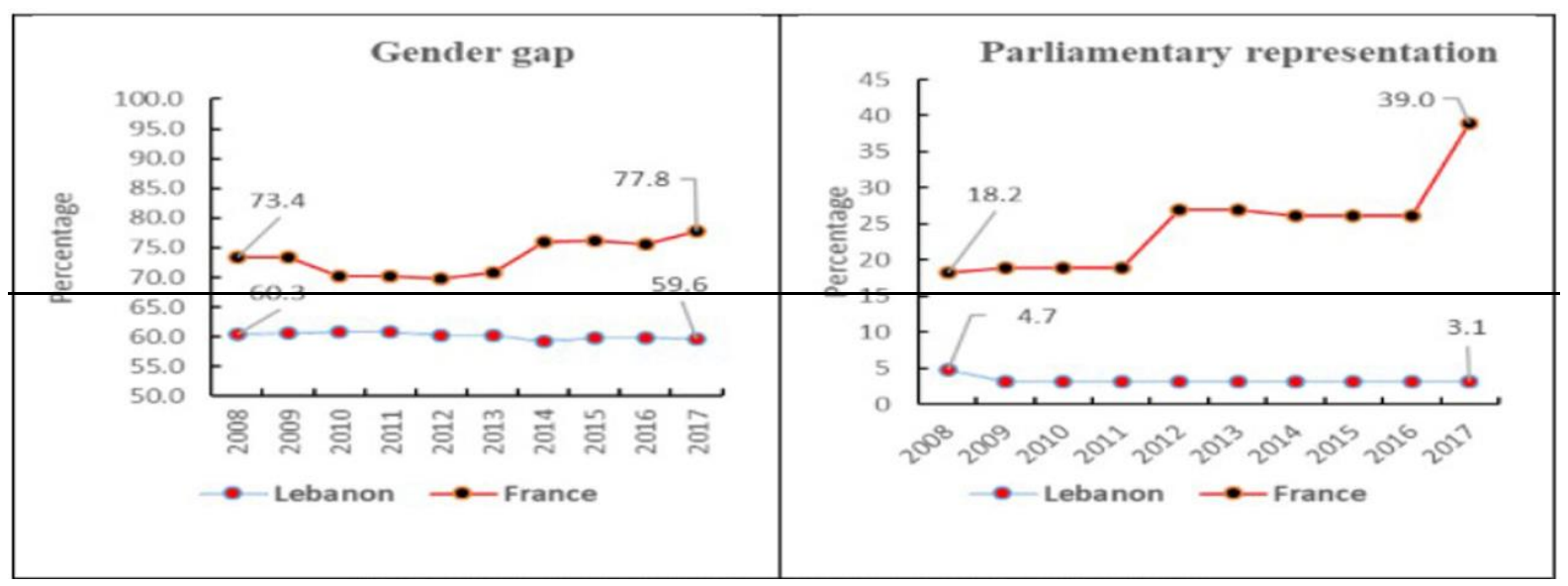

Figure 5. Gender gap and parliamentary representataion

\subsection{Freedom and Political and Civil Rights in Lebanon and France}

In this part, we will shed light on the report issued by Freedom House, a non- governmental organization in the United States, focusing on freedom, civil and political rights in every country of the world. First, we would like to mention that the score ranges between 1 and 7 , with 1 representing the highest rate and 7 the lowest level of freedom. Accordingly, the states are divided into three groups: those whose rating average ranges between 1.0 to 2.5 are considered Free, 3.0 to 5.0 Partly Free, and 5.5 to 7.0 Not Free. To give a concrete sense for the right picture of freedom in the world for 2018, the report shows the following proportions:

Figure (6) reveals that $55 \%$ of the world's countries live in Partly Free and Not Free modes. Inspecting figures (7) and (8), the civil and political rights are very different between Lebanon and France though there is almost the same Constitution. 


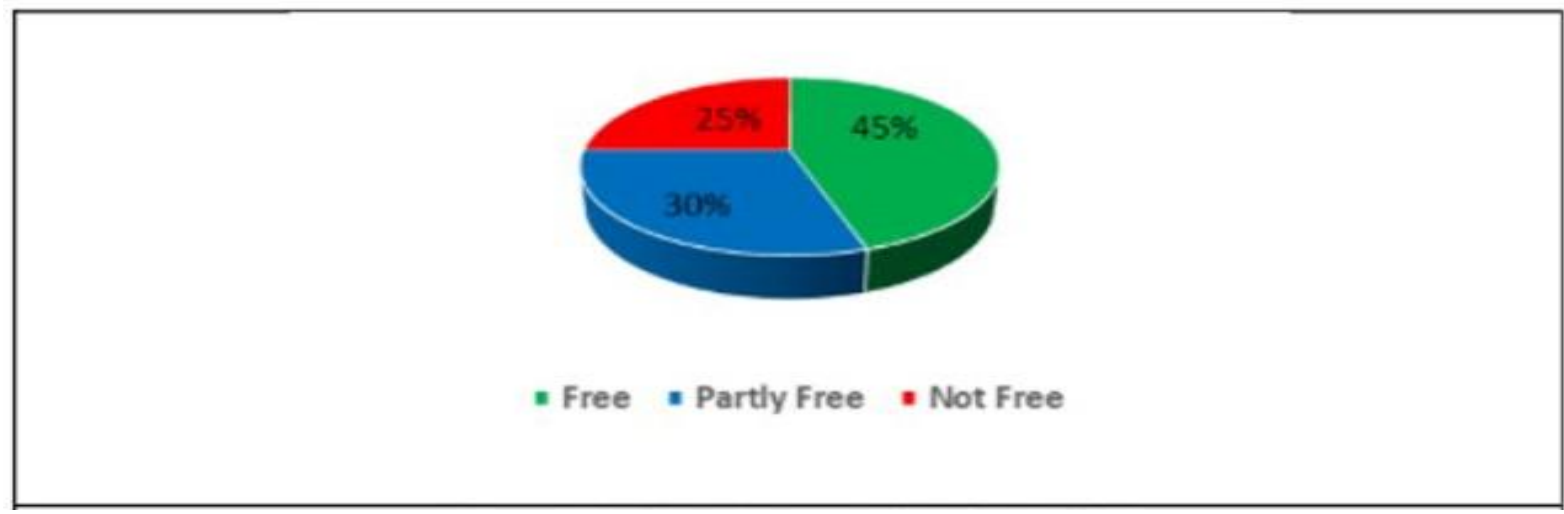

Figure 6. Freedom in the World 2018

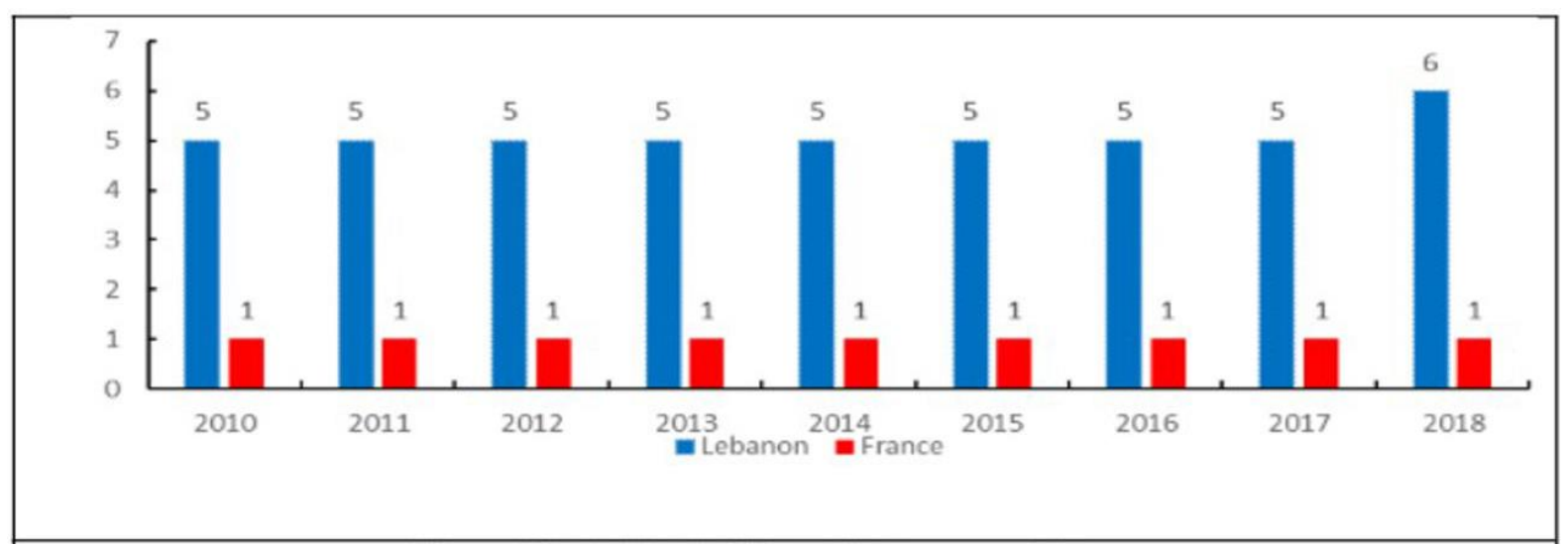

Figure 7. Political rights in Lebanon and France

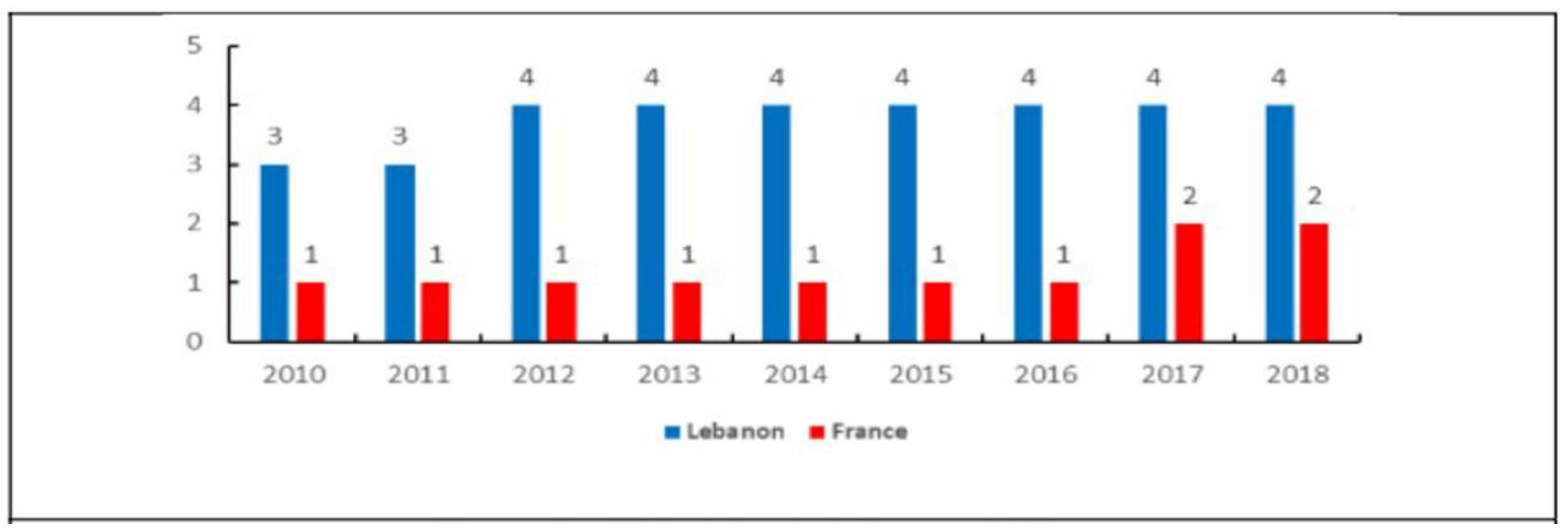

Figure 8. Civil rights in Lebanon and France

\section{Choice of Explanatory Variables for the Panel Data Model}

To get an idea about the importance of multicollinearity among the explanatory variables, the bivariate Pearson correlation coefficients are calculated in both countries, and the findings are in Tables (2) and (3) in the appendix. Focusing on Diagram (1), in Lebanon, we note a strong correlation between higher education $\left(\mathrm{X}_{2}\right)$, secondary education $\left(\mathrm{X}_{3}\right)$, labor force participation $\left(\mathrm{X}_{7}\right)$ and gender gap $\left(\mathrm{X}_{8}\right)$ and that's what drives us to avoid the multicollinearity problem (Mourad,M., 2017,498-579). Focusing on one of these variables, for example, retaining the 
higher education variable $\mathrm{X}_{2}$ in the panel data model. On one hand, there is a strong correlation between the variables $\mathrm{X}_{2}, \mathrm{X}_{3}$ and $\mathrm{X}_{8}$, on the other hand between the variables $\mathrm{X}_{2}$, $\mathrm{X}_{3}$ and $\mathrm{X}_{7}$. The Pearson correlation coefficient between $\mathrm{X}_{7}$ and $\mathrm{X}_{8}$ is not so much high. $\mathrm{A}$ priori, we can approximate our choice suggesting $\mathrm{X}_{2}$. In France, there is no multicollinearity among the variables $X_{2}, X_{3}, X_{7}$ and $X_{8}$. Diagram (2) is associated with the variables $X_{2}, X_{3}$, $\mathrm{X}_{6}$ and $\mathrm{X}_{7}$. There is an important heterogeneity between Lebanon and France concerning the bivariate Pearson correlations, similarly for the variables $\mathrm{X}_{1}, \mathrm{X}_{4}, \mathrm{X}_{5}$ and $\mathrm{X}_{10}$ (Diagram (3)). If we regress $\mathrm{X}_{6}$ on $\mathrm{X}_{10}$, then we find a Variance Inflation Factor (VIF) de 70.22 and then there is a multicollinearity between $\mathrm{X}_{6}$ and $\mathrm{X}_{10}$ and, therefore, we can retain the variable $\mathrm{X}_{6}$ as an explanatory variable. We note that a tedious calculation concerning the VIF was made and very strong multicollinearity was observed considering the 10 explanatory variables, especially for Lebanon where the VIF varies between 29.5 and 55573.2. We didn't include the results in the paper so as not to overload it with these kinds of calculations. To select the explanatory variables automatically, we have used the Stepwise Regression Method (SRM). For more details on this method (Mourad,M., 2017, 179-182). The findings due SRM reveal the stepping in the variables $\mathrm{X}_{5}$, Constant, $\mathrm{X}_{6}$ and $\mathrm{X}_{3}$ with $\mathrm{p}$-values $0.0000,0.0000,0.0000$ and 0.0101 respectively.

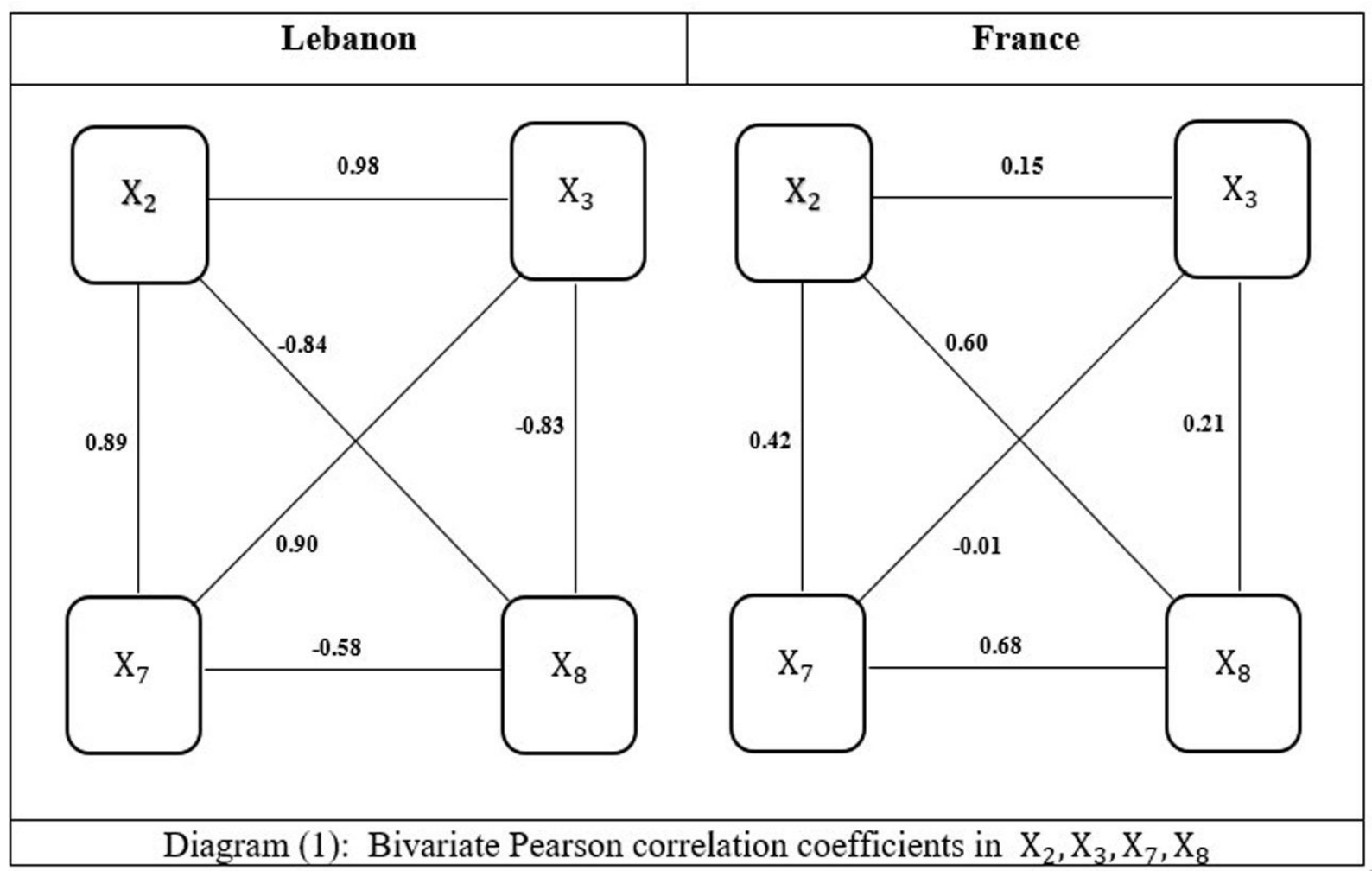



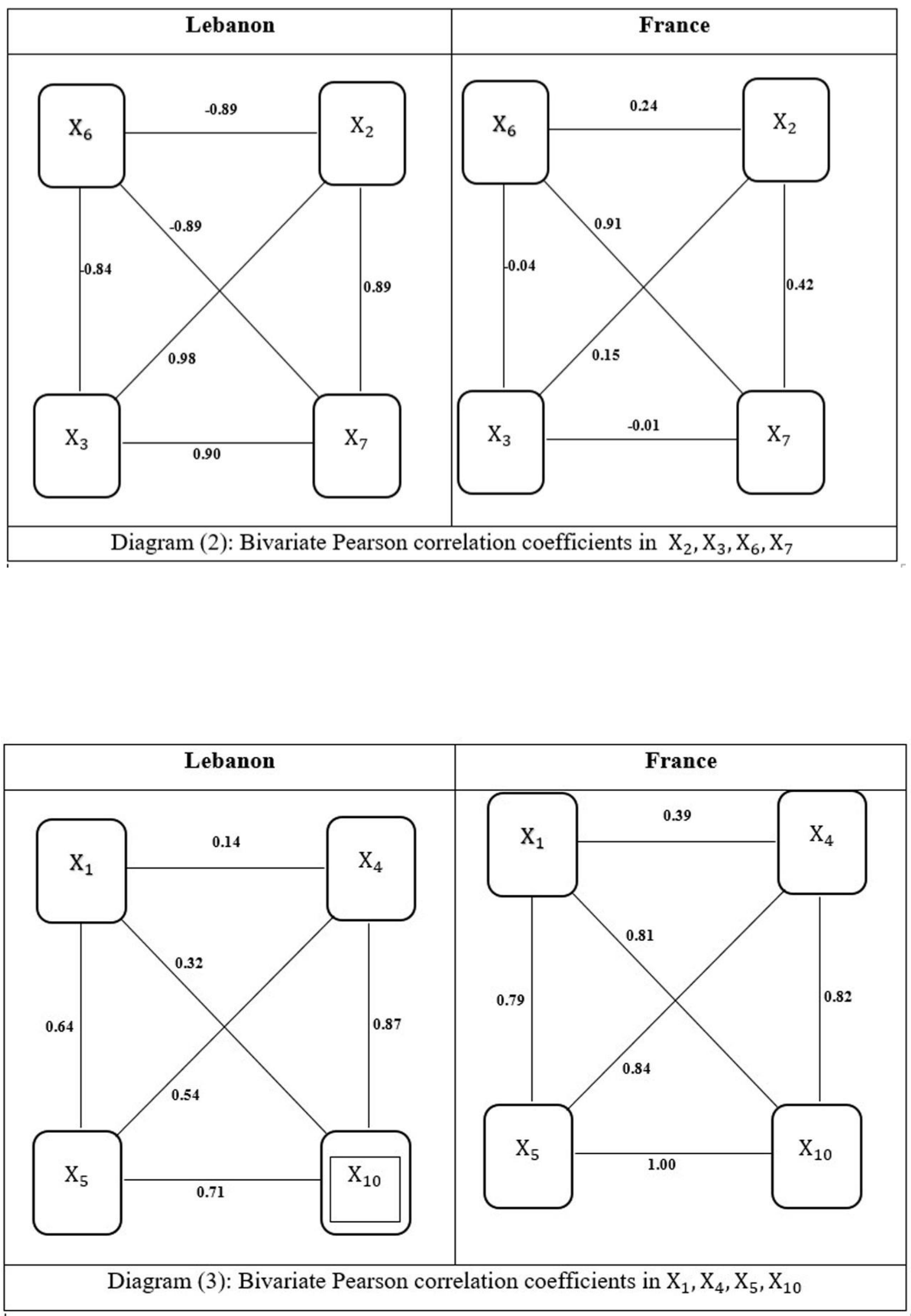


\section{Brief Literature Review}

Before embarking on the search for the appropriate model, it must be mentioned some of the studies that addressed economic growth effects on it. We begin with a very important book (Mourad M. , 2019a) dealing with panel data analysis, theory and practice, based on a great bibliography by examining all the sides that make this topic easily affordable by researchers. (Mourad, Sabah, \& Mourad, 2019b) carried out a very recent paper performing a panel data analysis considering the computer, communications and other services as a percentage of commercial service exports taken as a dependent variable and three explanatory variables related to the share of high technology exports in manufactured exports, researchers (per million) in research and development (R\&D), share of computer, communications and other services in commercial service imports. Also with (Mourad M. , 2018b), a panel co-integration analysis is carried out by considering the impact of trade on GDP in the World's top ten economies. (Mourad M. , 2018c) used Pedroni's procedure to study the long run equilibrium between the real GDP in GCC countries and six determinant variables such as the human development index, labor force, foreign direct investment, exports and imports as ratios of GDP and gross capital formation (\% of GDP). (Ahmed, Bhattacharya, Shaikh, Ramzan, \& Ozturk, 2017) performed a linear relationship between economic growth and economic determinants such as $\mathrm{CO} 2$ emissions, total energy consumption in cargo transport and commercial opening. (Saleh, Assaf, Ihalanayake, \& Lung, 2015) studied the contribution of tourism in GDP for the three countries, Bahrain, Jordan, Saudi Arabia concluding a long-term equilibrium between tourism growth and GDP. (Aboubacar, Xu, \& Ousseini, 2015) focused in whether the foreign aid (AID) has an important effect on economic growth in the member countries of the West African Economic and Monetary Union (WAEMU). (Adeleye, Adeteye, \& Adewuyi, 2015) studied the effect of international trade on economic growth in Nigeria.

\section{Panel Data Analysis: Fixed or Random Effects Model}

In the panel data, the research effort should focus on the distinction between three types of models: Pooled regression model, fixed effects model and random effects model. The strategy of choice begins by testing three types of null hypothesis according to (Hsiao, 1986), (Hurlin, 2012) and Mourad (2019a) using Fisher's test to obtain a decision by which we determine its nature homogeneous or heterogeneous. The way of testing passes through the levels and we will draw conclusions that reflect the relationship of variables to the dependent variable. This is a preliminary statistic that determines homogeneity or heterogeneity of the panel. We recall here that we will propose the following model:

$$
\begin{aligned}
Y_{\text {it }}=\beta_{0, \mathrm{i}}+\beta_{3, \mathrm{i}} \mathrm{X}_{3(\mathrm{it})}+\beta_{5, \mathrm{i}} \mathrm{X}_{5(\mathrm{it})}+\beta_{6, \mathrm{i}} \mathrm{X}_{6(\mathrm{it})}+\varepsilon_{\mathrm{it}} \\
\mathrm{K}=3, \mathrm{i} \in[1, \mathrm{~N}], \mathrm{T} \in[2001,2017]=[1, \mathrm{~T}]
\end{aligned}
$$

In matrix form, let us define the following:

$$
x_{i t}=\left(\mathrm{X}_{3(\mathrm{it})}, \mathrm{X}_{5(\mathrm{it})}, \mathrm{x}_{6(\mathrm{it})}\right)^{\prime}
$$




$$
\begin{gathered}
\mathfrak{B}^{i}=\left(\beta_{3, \mathfrak{i}^{i}} \beta_{5, \mathfrak{i}^{\mathrm{i}}} \beta_{6, \mathrm{i}}\right) \\
\mathfrak{B}_{i}=\left(\beta_{0, \mathrm{i}^{\prime}} \mathfrak{B}^{i}\right)^{\prime}
\end{gathered}
$$

And as a result, the model becomes: $\mathrm{Y}_{\mathrm{it}}=\beta_{0, \mathrm{i}}+\mathcal{X}_{i t}^{\prime} \mathfrak{B}^{i}+\varepsilon_{\mathrm{it}}$

In the literature, we have three tests (Mourad 2019b, p. 150-154):

First test:

$$
\begin{aligned}
& \mathrm{H}_{0}^{1}: \beta_{0, \mathrm{i}}=\beta_{0}, \mathfrak{B}^{i}=\mathfrak{B} \forall \mathrm{i}=1, \mathrm{~N} \\
& \mathrm{H}_{\mathrm{a}}^{1}: \exists(\mathrm{i}, \mathrm{j}) \in[1, \mathrm{~N}] / \beta_{0, \mathrm{i}} \neq \beta_{0, \mathrm{j}} \text { or } \mathfrak{B}^{\mathrm{i}} \neq \mathfrak{B}^{\mathrm{j}}
\end{aligned}
$$

Under the null hypothesis $\mathrm{H}_{0}^{1}$, we consider a pooled Regression Model (PRM) respecting the number of the imposed restrictions $\left[v_{1}=(K+1)(N-1)\right]$. Using the OLS method, we estimate the PRM and we save the residual sum of squares RSS ${\text { pooled, } r_{1}}_{\text {where }} r_{1}$ designates the restrictions under $\mathrm{H}_{0}^{1}$. Then we consider ( $\left.\mathrm{N}=2\right)$ models of multiple linear regressions, a model for each country, and we keep the residual sum of squares associated with each country $\mathrm{RSS}_{\mathrm{i}}^{1}, \mathrm{i}=1, \mathrm{~N}$ and finally we calculate $\mathrm{RSS}_{1, \mathrm{v}_{2}}=\sum_{\mathrm{i}=1}^{\mathrm{N}} \mathrm{RSS}_{1}^{\mathrm{i}} \quad$ where $\left[v_{2}=\mathrm{N}(\mathrm{T}-\mathrm{K}-1)\right]$ degrees of freedom. If the null hypothesis is true, then we calculate the F-statistic given by:

$$
\mathrm{F}_{1}=\frac{\frac{\left[\mathrm{RSS}_{\text {pooled, } \mathrm{r}_{1}}-\mathrm{RSS}_{1, \mathrm{v}_{2}}\right]}{\mathrm{v}_{1}}}{\frac{\mathrm{RSS}_{1, \mathrm{v}_{2}}}{\mathrm{v}_{2}}}
$$

And we compare it to the tabulated value $\mathrm{F}_{0.05 ; \mathrm{v}_{1} ; \mathrm{v}_{2}}$. If $\mathrm{F}_{1}>\mathrm{F}_{0.05 ; \mathrm{v}_{1} ; \mathrm{v}_{2}}$ then we reject $\mathrm{H}_{0}^{1}$.

If we accept $\mathrm{H}_{0}^{1}$ then we obtain a homogeneous panel data model. In fact, if $\mathrm{H}_{0}^{1}$ is rejected Then we move on to the second step which consists of determining whether the heterogeneity comes from the coefficients $\mathfrak{B}^{i}$. 
Second test:

$$
\begin{gathered}
\mathrm{H}_{0}^{2}: \mathfrak{B}^{i}=\mathfrak{B} \forall \mathrm{i}=1, \mathrm{~N} \\
\mathrm{H}_{\mathrm{a}}^{2}: \exists(\mathrm{i}, \mathrm{j}) \in[1, \mathrm{~N}] / \mathfrak{B}^{\mathrm{i}} \neq \mathfrak{B}^{\mathrm{j}}
\end{gathered}
$$

In this test, no restriction is imposed on the parameters $\left(\beta_{0, \mathrm{i}}, i=1, \mathrm{~N}\right)$. Using the so-called method (Within estimation) we obtain the residual sum of squares $\operatorname{RSS}_{\text {pooled, } r_{2}}$ where $r_{2}$ designates the restrictions under $\mathrm{H}_{0}^{2}$ with restrictions $\left[\mathrm{v}_{1}=\mathrm{K}(\mathrm{N}-1)\right]$. Like our path in the first test, by the same method we estimate a model for each country and we retain the $\left(\mathrm{RSS}_{2}=\sum_{\mathrm{i}=1}^{\mathrm{N}} \mathrm{RSS}_{\text {Within }}^{\mathrm{i}}\right)$ with $\left[\mathrm{v}_{2}=\mathrm{N}(\mathrm{T}-\mathrm{K}-1)\right]$ as degrees of freedom. Under the null hypothesis $\mathrm{H}_{0}^{2}$, we calculate the following F-statistic:

$$
\mathrm{F}_{2}=\frac{\frac{\left[\mathrm{RSS}_{\text {within, } \mathrm{r}_{2}}-\mathrm{RSS}_{2, \mathrm{v}_{2}}\right]}{\frac{\mathrm{v}_{1}}{\mathrm{RSS}_{2, \mathrm{v}_{2}}}}}{\mathrm{v}_{2}}
$$

If $\mathrm{F}_{2}>\mathrm{F}_{0.05 ; \mathrm{v}_{1} ; \mathrm{v}_{2}}$ then $\mathrm{H}_{0}^{1}$ is rejected. If $\mathrm{H}_{0}^{2}$ is accepted then we retain the panel structure and we then seek to determine in a third step if the coefficients $\left(\beta_{0, i}\right)$ have an individual dimension. If, on the other hand, $\mathrm{H}_{0}^{2}$ is rejected then the panel structure is rejected and by consequence the estimated vector $\mathfrak{B}^{i}$ will be made country by country.

Third test:

$$
H_{0}^{3}: \beta_{0, i}=\beta_{0} \quad \forall i=1, N
$$

$H_{a}^{3}: \exists(i, j) \in[1, N] / \quad H_{a}^{3}: \beta_{0, i} \neq \beta_{0, j}$

Under $\mathrm{H}_{0}^{3}$, we impose $\left(\mathfrak{B}^{i}=\mathfrak{B} \forall \mathrm{i}=1, \mathrm{~N}\right)$. There will be available $\left(v_{1}=(\mathrm{N}-1)\right)$ of restrictions. Under $\mathrm{H}_{\mathrm{a}}^{3}$, the $\left(\mathfrak{B}^{\mathrm{i}}, \mathrm{i}=1, \mathrm{~N}\right)$ are the same but the $\beta_{0, \mathrm{i}}$ differ according to the countries . Using the pooled estimation method, we guarantee $\left(\operatorname{RSS}_{\text {pooled, } \mathbf{r}_{3}}\right)$ and using 
Within Estimation Method, we retain $\left(\operatorname{RSS}_{3}=\operatorname{RSS}_{2, \mathrm{r}_{2}}\right)$ with $\left(\mathrm{v}_{2}=\mathrm{N}(\mathrm{T}-1)-\mathrm{K}\right)$ as degrees of freedom. Under the null hypothesis $\mathrm{H}_{0}^{3}$, we calculate the following F-statistic:

$$
\mathrm{F}_{3}=\frac{\frac{\left[\mathrm{RSS}_{3, \mathrm{r}_{3}}-\mathrm{RSS}_{2, \mathrm{r}_{2}}\right]}{\frac{\mathrm{v}_{1}}{\mathrm{vSS}_{2, \mathrm{r}_{2}}}}}{\mathrm{v}_{2}}
$$

If $\mathrm{F}_{3}>\mathrm{F}_{0.05 ; \mathrm{v}_{1} ; \mathrm{v}_{2}}$ then we reject $\mathrm{H}_{0}^{3}$ and by consequence we get a panel model with individual effects. If we accept $\mathrm{H}_{0}^{3}$ then we retrieve an homogeneous panel data model. The findings of the three tests above are given in the following table (1):

Table 1. Homogeneous or Heterogeneous panel: Fisher's test

\begin{tabular}{|c|c|c|c|}
\hline Null hypothesis & Primary data $^{(\mathbf{a})}$ & $\begin{array}{l}\text { Log transformed } \\
\text { data (b) }\end{array}$ & $\begin{array}{l}\text { Critical values at } \\
\mathbf{5} \%\end{array}$ \\
\hline $\mathbf{H}_{\mathbf{0}}^{\mathbf{1}}$ & $0.93^{*}$ & $0.99^{*}$ & 3.26 \\
\hline $\mathbf{H}_{\mathbf{0}}^{\mathbf{2}}$ & $0.82^{*}$ & $1.09^{*}$ & 3.49 \\
\hline $\mathbf{H}_{\mathbf{0}}^{\mathbf{3}}$ & $1.30^{*}$ & $0.66^{*}$ & 4.54 \\
\hline Acceptance the null hypothesis at significance level of $5 \%$. \\
\hline
\end{tabular}

This profound adequation of the responses in the $\mathrm{H}_{0}^{\mathrm{i}}, i=1,2,3$ tests in both primary data and Log transformed data, led us directly to consider the homogeneous panel data model.

Since the size of the time series is relatively short, we have introduced two binary variables:

$$
\mathrm{D}_{\mathrm{L}}=\left\{\begin{array}{lr}
0 & \text { France } \\
1 & \text { Lebanon }
\end{array} \quad \mathrm{D}_{\mathrm{F}}=\left\{\begin{array}{lr}
1 & \text { France } \\
0 & \text { Lebanon }
\end{array}\right.\right.
$$

In the following, we will use the log-transformed data. Why do this? Four reasons can be cited. The first is to make data more "normal", or symmetric. In fact, a log transformation help us meet the assumption of data normality. The second is to help meet the assumption of 
constant variance in the context of linear model. The third leads to make a non-linear relationship more linear. The fourth is to easily interpret the estimated coefficients associated to the explanatory variables and to calculate their impact on the dependent variable. We have to choose now among three model: pooled regression model, fixed effects model and random effects model. The first is estimated by Ordinary Least Squares (OLS) method, the second is estimated by Least Squares Dummy Variable (LSDV) method and the third called Error Components Model (ECM) estimated by the Feasible Generalized Least Squares (FGLS) method. The three estimate models are in Tables $2-4$, respectively.

Table 2. Panel regression-estimation by pooled sample

\begin{tabular}{|c|c|c|c|c|}
\hline Variable & Coefficient & Std. error & t-statistic & Significance \\
\hline Constant & 14.270 & 1.430 & 9.977 & 0.0000 \\
\hline $\mathbf{X}_{3}$ & 0.498 & 0.171 & 2.918 & 0.0101 \\
\hline $\mathbf{X}_{\mathbf{5}}$ & 3.243 & 0.190 & 17.036 & 0.0000 \\
\hline $\mathbf{X}_{\mathbf{6}}$ & -1.194 & 0.174 & -6.853 & 0.0000 \\
\hline \multicolumn{2}{r}{$\mathrm{F}(3,16)=12488.91 ;$ Standard error of estimate=0.048956 } \\
\hline
\end{tabular}

Table 3. Panel regression-estimation by least squares dummy variable

\begin{tabular}{|l|c|c|c|c|}
\hline Variable & Coefficient & Std. error & t-statistic & Significance \\
\hline $\mathbf{X}_{\mathbf{3}}$ & 0.558 & 0.188 & 2.974 & 0.0095 \\
\hline $\mathbf{X}_{\mathbf{5}}$ & 2.426 & 1.026 & 2.364 & 0.0320 \\
\hline $\mathbf{X}_{\mathbf{6}}$ & -1.074 & 0.230 & & 0.0003 \\
\hline IDUMMIES(1) & 17.430 & 4.157 & 4.678 & 0.0008 \\
\hline IDUMMIES(2) & 16.540 & 3.152 & 5.248 & 0.0001 \\
\hline \multicolumn{5}{|r|}{ F(4,15) $=9166.28 ;$ Standard error of estimate $=0.049489$} \\
\hline
\end{tabular}


Table 4. Panel regression-estimation by random effects

\begin{tabular}{|c|c|c|c|c|}
\hline Variable & Coefficient & Std. error & t-statistic & Significance \\
\hline Constant & 14.270 & 1.4458 & 9.87 & 0.0000 \\
\hline $\mathbf{x}_{3}$ & 0.498 & 0.1726 & 2.887 & 0.0038 \\
\hline$X_{5}$ & 3.243 & 0.1924 & 16.853 & 0.0000 \\
\hline$x_{6}$ & -1.194 & 0.1761 & -6.779 & 0.0000 \\
\hline \multicolumn{5}{|c|}{$\begin{array}{l}\mathrm{RSS}=0.03835 ; \mathrm{Su}=\mathrm{Standard} \text { error of estimate }=0.04895 ; \mathrm{S} \alpha=\text { Individual-specific standard } \\
\text { error }=0.0000 ; \mathrm{S} \varepsilon=\text { Purely random standard error }=0.0495 ; \text { Hausman test }(2)=0.6574 \text {; } \\
\text { Significance Level }=0.7199\end{array}$} \\
\hline
\end{tabular}

Note: The number of degrees of freedom of Hausman test is the rank of the difference in the variance matrices. When the difference is positive definite, this is the number of common coefficients in the models being compared.

Choice between pooled OLS regression model and LSDV model:

Testing the null hypothesis versus the alternative, see Mourad et al. (2019a)

$$
\begin{aligned}
& \mathrm{H}_{0}: \alpha_{1}=\alpha_{2} \\
& \mathrm{H}_{\mathrm{a}}: \alpha_{1} \neq \alpha_{2}
\end{aligned}
$$

$F(1,15)=17.578402$ with Significance Level 0.00078445. It is therefore the null is rejected and we conclude that the LSDV model is preferred compared to pooled model.

\section{Choice between fixed effects model and random effects model:}

According to (Hausman A., 1978) (Hausman \& Taylor, 1981) testing now the null hypothesis vs the alternative:

$$
\begin{gathered}
\mathbf{H}_{\mathbf{0}} \text { : Random effects (RE) are preferred } \\
\mathbf{H}_{\mathbf{a}} \text { : Fixed effects (FE) is preferred }
\end{gathered}
$$

In the Table (4), since the Hausman test $(2)=0.6574$; Significance Level $=0.7199$, we conclude that the null is accepted at \% significance level. This means that the individual 
effects are random with an average of zero and a constant variation added as random component to the random error of the model. At the end of this statistical procedure, the random effects model can be proposed to explain the observable individual and temporal heterogeneity.

\section{Conclusion and Recommendations}

At the end of this search, we come to the following points:

Comparing the history of women's granting of civil and political Rights, in particular women's right to political participation in 1945, and the actual number of participations today in France, between the date of granting the women's right in 1953 and the actual current number, we find a little time difference in return, a significant difference in participation rate, in France for example, half of the cabinet is women, while in Lebanon it did not exceed $13 \%$ in the 2019 government.

By reviewing the legal texts in force in Lebanon that deal with the civil and political rights of both sexes, they are, to some extent, sufficient, and what is actually lacking is not the texts, but the actual means of application.

The results of the proposed Random Effects Model (REM) inform the decision makers of the following:

If the proportion of female teachers in secondary education $1 \%$ then the real GDP will increase about $0.5 \%$. This result highlights the importance of women's participation in the rehabilitation of the young men and women specialization going to colleges and universities and so the positive effects on the level of economic growth. Also if the female to male ratio in labor force participation increases of $1 \%$ then real output would increase about $3.24 \%$. This is a great indicator for decision-makers to focus on increasing the female workforce within the total workforce in Lebanon or France. The women's vulnerable employment plays a negative role in the real gross domestic product. This is a natural thing we expected before the estimate model. In fact, if this employment rate increases $1 \%$, the real GDP will decrease about $1.19 \%$. This must be on the relevant authorities particularly in Lebanon, to reduce the aggravation of this category of female employment, focusing its decline leading to the economic growth in the country.

Finally, we suggest two critical recommendations:

1- Concerned authorities in Lebanon, government and decision makers, should develop an ambitious plan to provide women with respectable and stable work because women's vulnerability to risks in the workplace affects the percentage of their employment, and thus affects economic growth negatively.

2- Effective involvement of women in the labor force should take place because this has a significant impact on the economic growth. Participation of women in Lebanese political life should also be strengthened as Lebanon is still far from where France is in this domain. For this reason, the political and educational rights of women should be activated by granting 
them quotas, which guarantees equal opportunities for both men and women in participating in our country's progress.

\section{References}

Aboubacar, B., Xu, D. Y., \& Ousseini, A. (2015). Foreign Aid's Effect on Economic Growth, New Results from WAEMU's Countries. Theoretical Economics Letters, 5, 425-430. https://doi.org/10.4236/tel.2015.53049

Adeleye, J. O., Adeteye, O. S., \& Adewuyi, M. O. (2015). Impact of International Trade on Economic Growth in Nigeria. International Journal of Financial Research, 6(3), 163-172. https://doi.org/10.5430/ijfr.v6n3p163

Ahmed, K., Bhattacharya, M., Shaikh, Z., Ramzan, M., \& Ozturk, I. (2017). Emission intensive growth and trade in the era of the Association of Southeast Asian Nations (ASEAN) integration: An empirical investigation from ASEAN-8. Journal of Cleaner Production, 154, 530-540. https://doi.org/10.1016/j.jclepro.2017.04.008

Hausman, A. (1978). Specification Test in econometrics. Econometrica, 46, 1241-1271. https://doi.org/10.2307/1913827

Hausman, A. J., \& Taylor, E. W. (1981). Panel Data and Unobservable Individual Effects. Econometrica, 49, 1377-1398. https://doi.org/10.2307/1911406

Hsiao, C. (1986). Analysis of panel data. Econometric society monographs, 11. Cambridge University Press, New York.

Hurlin, C. (2012). L’Econométrie des Données de Panel-Modèles Linéaires Simples. https://www.univ-orleans.fr/deg/masters/ESA/CH/CoursPanel_Chap1.pdf.

Mourad, M. (2017). Econometric from Theory to Practice, I. Beirut, Lebanon: Lebanese University, Central Administration, Museum.

Mourad, M. (2018a, 11). Management Governance Analysis in the Arab World: MANOVA Approach. Journal of Public Administration and Governance, 8(4), 1-19. https://doi.org/10.5296/jpag.v8i4.13766

Mourad, M. (2018b). Trade and GDP in World's Top Economies: Panel Co-integration Analysis. Arabian Journal of Business and Management Review, 8(5), 1-8.

Mourad, M. (2018c). Vital economic determinants and real GDP in GCC countries: Panel Co-Integration Analysis. Revue of Economics and Business Administration, 2(2), 141-168.

Mourad, M. (2019a). Econometric from Theory to Practice, II. Lebanese University, Central Administration, Museum, Beirut, Lebanon.

Mourad, M., Sabah, H., \& Mourad, H. (2019b). Impact of the Technological Developments to the Computer and Communication Service Exports: Panel Data Analysis. Arabian Journal of Business and Management Review, 9(1), 1-10.

Okun, A. (1962). Potential GNP: Its Measurement and Significance. In Proceedings of the Business and Economics Statistics Section. American Statistical Association, 98-103. 
Saleh, A. S., Assaf, G., Ihalanayake, R., \& Lung, S. (2015). A Panel Cointegration Analysis of the Impact of Tourism on Economic Growth: Evidence from the Middle East Region. International Journal of Tourism Research, 17(3), 209-220. https://doi.org/10.1002/jtr.1976

\section{Appendices}

App 1. Basic statistical characteristics

\begin{tabular}{|c|c|c|c|c|c|c|c|c|}
\hline \multicolumn{4}{|r|}{ France } & \multicolumn{4}{|c|}{ Lebanon } & \multirow{2}{*}{ Variables } \\
\hline Max & Min & $\begin{array}{r}\text { Standard } \\
\text { dev }\end{array}$ & Mean & $\operatorname{Max}$ & Min & $\begin{array}{r}\text { Standard } \\
\text { dev }\end{array}$ & Mean & \\
\hline 10.03 & 7.45 & 0.76 & 9.27 & 10.70 & 10.37 & 0.11 & 10.54 & $\mathrm{X}_{1}$ \\
\hline 40.92 & 36.79 & 1.20 & 37.96 & 52.19 & 38.31 & 5.11 & 44.71 & $\mathrm{X}_{2}$ \\
\hline 61.81 & 58.90 & 0.78 & 59.73 & 70.64 & 54.53 & 5.89 & 62.01 & $\mathrm{X}_{3}$ \\
\hline 87.81 & 82.36 & 1.76 & 83.78 & 87.85 & 85.74 & 0.76 & 86.91 & $\mathrm{X}_{4}$ \\
\hline 84.11 & 81.62 & 0.84 & 82.91 & 32.99 & 31.20 & 0.51 & 32.46 & $\mathrm{X}_{5}$ \\
\hline 6.16 & 4.80 & 0.45 & 5.63 & 15.91 & 14.86 & 0.34 & 15.49 & $\mathrm{X}_{6}$ \\
\hline 67.61 & 65.13 & 0.89 & 66.41 & 25.90 & 24.15 & 0.51 & 25.17 & $\mathrm{X}_{7}$ \\
\hline 0.78 & 0.70 & 0.03 & 0.73 & 0.61 & 0.59 & 0.01 & 0.60 & $\mathrm{X}_{8}$ \\
\hline 39.00 & 18.20 & 6.36 & 24.63 & 4.7 & 3.10 & 0.51 & 3.26 & $X_{9}$ \\
\hline 46.97 & 46.35 & 0.21 & 46.68 & 24.45 & 22.64 & 0.55 & 23.86 & $\mathrm{X}_{10}$ \\
\hline
\end{tabular}

App 2. bivariate Pearson correlation coefficients of the Lebanese variables

\begin{tabular}{|c|c|c|c|c|c|c|c|c|c|c|}
\hline $\mathrm{X}_{1}$ & $\mathrm{X}_{2}$ & $\mathrm{X}_{3}$ & $\mathrm{X}_{4}$ & $\mathrm{X}_{5}$ & $\mathrm{X}_{6}$ & $\mathrm{X}_{7}$ & $\mathrm{X}_{8}$ & $\mathrm{X}_{9}$ & $\mathrm{X}_{10}$ & Variables \\
\hline 1 & -0.14 & -0.07 & 0.14 & 0.64 & 0.23 & 0.14 & 0.20 & -0.57 & 0.32 & $\mathrm{X}_{1}$ \\
\hline-0.14 & 1 & & & & & & & & & $\mathrm{X}_{2}$ \\
\hline & & 1 & & & & & & & & $\mathrm{X}_{3}$ \\
\hline 0.07 & 0.98 & & 0.79 & 0.25 & -0.84 & 0.90 & -0.83 & -0.45 & 0.86 & \\
\hline 0.14 & 0.76 & 0.79 & 1 & & & & & & & $\mathrm{X}_{4}$ \\
\hline & & & & 1 & & & & & & $\mathrm{X}_{5}$ \\
\hline
\end{tabular}




\begin{tabular}{|c|c|c|c|c|c|c|c|c|c|c|}
\hline 0.23 & -0.89 & -0.84 & -0.77 & -0.33 & & -0.89 & 0.56 & 0.44 & -0.79 & $\mathrm{X}_{6}$ \\
\hline 0.14 & 0.89 & 0.90 & 0.88 & 0.61 & -0.89 & & -0.58 & -0.71 & 0.98 & $\mathrm{X}_{7}$ \\
\hline 0.20 & -0.84 & -0.83 & -0.58 & 0.15 & 0.56 & -0.58 & & 0.11 & -0.53 & $\mathrm{X}_{8}$ \\
\hline-0.57 & -0.40 & -0.45 & -0.54 & -0.86 & 0.44 & -0.71 & & 1 & & \\
\hline 0.32 & 0.82 & 0.86 & 0.87 & 0.71 & -0.79 & 0.98 & -0.53 & -0.78 & 1 & $\mathrm{X}_{9}$ \\
\hline
\end{tabular}

App 3. bivariate Pearson correlation coefficients of the France variables

\begin{tabular}{|c|c|c|c|c|c|c|c|c|c|c|}
\hline $\mathrm{X}_{1}$ & $\mathrm{X}_{2}$ & $\mathrm{X}_{3}$ & $\mathrm{X}_{4}$ & $\mathrm{X}_{5}$ & $\mathrm{X}_{6}$ & $\mathrm{X}_{7}$ & $\mathrm{X}_{8}$ & $\mathrm{X}_{9}$ & $\mathrm{X}_{10}$ & Variables \\
\hline-0.13 & -0.13 & 0.07 & 0.39 & 0.79 & 0.87 & 0.78 & 0.23 & 0.50 & 0.81 & $\mathrm{X}_{1}$ \\
\hline 0.07 & 0.15 & 1 & 0.06 & -0.03 & -0.04 & -0.01 & 0.21 & -0.06 & -0.02 & $\mathrm{X}_{3}$ \\
\hline 0.39 & 0.84 & 0.06 & 1 & 0.84 & 0.71 & 0.83 & 0.76 & 0.85 & 0.82 & $\mathrm{X}_{4}$ \\
\hline 0.79 & 0.43 & -0.03 & 0.84 & 1 & 0.94 & 0.99 & 0.67 & 0.83 & 0.99 & $\mathrm{X}_{5}$ \\
\hline 0.87 & 0.24 & -0.04 & 0.71 & 0.94 & 1 & 0.91 & 0.57 & 0.66 & 0.95 & $\mathrm{X}_{6}$ \\
\hline 0.78 & 0.42 & -0.01 & 0.83 & 0.99 & 0.91 & 1 & 0.68 & 0.84 & 0.99 & $\mathrm{X}_{7}$ \\
\hline 0.23 & 0.60 & 0.21 & 0.76 & 0.67 & 0.57 & 0.68 & 1 & 0.59 & 0.65 & $\mathrm{X}_{8}$ \\
\hline 0.50 & 0.61 & -0.06 & 0.85 & 0.83 & 0.66 & 0.84 & 0.59 & 1 & 0.82 & $\mathrm{X}_{9}$ \\
\hline 0.81 & 0.39 & -0.02 & 0.82 & 0.95 & 0.99 & 0.65 & 0.82 & 0.95 & 1 & $\mathrm{X}_{10}$ \\
\hline
\end{tabular}

\section{Copyright Disclaimer}

Copyright for this article is retained by the author(s), with first publication rights granted to the journal.

This is an open-access article distributed under the terms and conditions of the Creative Commons Attribution license (http://creativecommons.org/licenses/by/4.0/). 